ORIGINAL ARTICLE

\title{
Impact of in vitro fertilization by refrigerated versus frozen buffalo semen on developmental competence of buffalo embryos
}

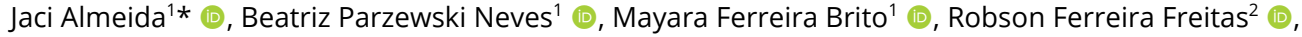

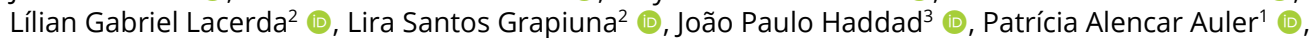 \\ Marc Henry ${ }^{1}(1)$ Pampulha, Belo Horizonte, MG, Brasil
${ }^{2}$ Laboratório BH Embriões, Belo Horizonte, MG, Brasil
${ }^{3}$ Departamento de Medicina Veterinária Preventiva, Escola de Veterinária, Universidade Federal de Minas Gerais, Campus Pampulha, Belo Horizonte, MG, Brasil \\ 1Departamento de Clínica e Cirurgia Veterinária, Escola de Veterinária, Universidade Federal de Minas Gerais, Campus
}

How to cite: Almeida J, Neves BP, Brito MF, Freitas RF, Lacerda LG, Grapiuna LS, Haddad JP, Auler PA, Henry M. Impact of in vitro fertilization by refrigerated versus frozen buffalo semen on developmental competence of buffalo embryos. Anim Reprod. 2020;17(4):e20200033. https://doi.org/10.1590/1984-3143-AR2020-0033

\begin{abstract}
The objective of this study was to evaluate the fertility of buffalo semen for in vitro embryo production (IVEP) by comparing the effectiveness of refrigerated versus frozen semen. Three OPU sessions were held at 30-day intervals. For oocyte fertilization three buffalo bulls were used, one per session. At each OPUIVEP session, one ejaculate was collected and divided into two equal aliquots. Each aliquot was either refrigerated at $5^{\circ} \mathrm{C} / 24$ hours or frozen. A TRIS extender containing $10 \%$ low density lipoproteins, $0.5 \%$ lecithin and $10 \mathrm{mM}$ acetylcysteine was used adding 7\% glycerol for freezing. Sperm motility/kinetic was evaluated by CASA and sperm membrane integrity by the hypoosmotic swelling test. The evaluations were performed at $0 \mathrm{~h} \mathrm{(post} \mathrm{final} \mathrm{dilution} \mathrm{at} 37^{\circ} \mathrm{C}$ ), at 4 and $24 \mathrm{hs}$ post-incubation at $5^{\circ} \mathrm{C}$ and post-thaw. At $24 \mathrm{hs}$ incubation and immediately post thaw sperm cells were used for in vitro fertilization of buffalo oocytes equally distributed between both groups. Cleavage rates and embryo development were followed. The embryo/matured and embryo/cultured rates were $25.4 \times 14.0 \%$ and $29.4 \times 18.5 \%(P<0.05)$, for chilled and frozen semen, respectively. It is concluded that cooled semen can be used for in vitro embryo production in buffalo and that a better efficiency may be expected for cooled compared to frozen semen.
\end{abstract}

Keywords: oocyte donors, OPU, in vitro fertilization.

\section{Introduction}

Since the first pregnancy in buffalo resulting from an embryo produced in vitro (Madan et al., 1992) and the first calf born in Brazil (Ohashi et al., 2006) reproductive biotechnologies in buffalos such as intracytoplasmic sperm injection (ICSI), transgenes, cloning and even ovum pick-up (OPU) in two months old buffalo calf have been done (Bernardes, 2017). All this resulted in some parts of the world in commercial exploitation of in vitro production of embryos (IVEP) in Buffalos (ABS Brasil, 2016). From 1991 to 2008 more than 100 publication have been released reporting high oocyte maturation index (80\%), moderate cleavage rate $(50 \%)$ and moderate to low blastocyst rate (20\%) in the buffalo specie (Surresh et al., 2009 and Soliman et al., 2018). However, the use of the technique in this species still faces some limitations. The production of embryo rates per egg collection section is still low (Salzano et al., 2018; Baruselli et al., 2020), thus increasing the cost of pregnancy 3 to 4 times when compared to what was achieved in zebu (Ohashi et al., 2017). 
Efficiency (OPU/IVEP) in buffalo is necessary to enhance the use of superior genetic material. OPU can be performed on prepubertal, anestrus, cycling and even pregnant buffalo, however, some anatomophysiological peculiarities, such as lower weight and size of ovaries compared to cows (Vitoria, 1997), lower total primordial follicular number in buffalo when compared to cows (Danell, 1987; Erickson, 1966; Baruselli et al., 1997; Gimenes et al., 2009; Campanile et al., 2010; Santos et al., 2013 and Liang et al., 2016), greater follicular rate atresia in buffaloes (Le Van Ty et al., 1989; Ocampo et al., 1994; Perera, 2011; Santos et al., 2013), low eligibility rate for buffalo oocytes $(38.4 \%)$ for the culture due to less compaction and fewer cumulus layers (Ohashi et al., 2003; Gimenes et al., 2010; Marin et al., 2019) and the seasonality effects on the quality of oocytes (Gimenes et al., 2010; Gasparrini, 2018) are limiting factors for in vitro embryo production (IVEP) in buffalo species (Salzano et al., 2018; Baruselli et al., 2020).

Among all attempts to improve the efficiency of the IVEP no reports were found proposing the use of oocyte fertilization by cooled semen. The process of freezing semen is known to "pre-capacitate" sperm cells which is an advantage for the IVEP. Cooling sperm cells, at least in the beginning of the incubation period, result in less injury to the sperm cells which could not induce the pre-capacitate stage required for IVF. To our knowledge, there are no reports in buffalo using cooled and comparing cooled to frozen semen for in vitro fertilization. As each steps of the process of IVEP may contribute for general improvement the aim of the present study was to evaluate the efficiency of the use of cooled semen in substitution of frozen semen to produce buffalo embryo in vitro.

\section{Material and methods}

\section{Ethics}

This study was approved by the Ethics Committee for Domestic Animals of the Universidade Federal de Minas Gerais - UFMG (protocol CEUA UFMG 368/2015), following the ethical principles for experiments with animals.

\section{Site of the experiment and execution period}

The experiment was carried out at the "Centro de Biotecnologia em Bubalinocultura", Fazenda Modelo - Pedro Leopoldo - Estado de Minas Gerais, Brasil at a $710 \mathrm{~m}$ altitude, $19^{\circ} 37^{\prime} 05^{\prime \prime}$ South latitude and 44002'55 West longitude. Ovum pick-up sessions were performed from September to November at 30 days intervals.

\section{Animals}

Three Murrah bulls (Bubalus bubalis) of average five years old, body condition score $=4(1-5)$ and average weight of $920 \mathrm{~kg}$ were used as semen donors. All were maintained isolated from females and had good fertility records.

OPU sessions were performed in 25 crossbred buffalo (Murrah $x$ Mediterranean) aging 3 to 11 years, body condition score 3 to $5(1-5)$ and average body weight of $625 \mathrm{~kg}$. Two third were lactating females and all were approved at the gynecological evaluation. The herd was maintained at pasture with mineral supplementation and water ad libitum.

\section{Semen collection and evaluation}

Three seminal donors were conditioned to artificial vagina using a buffalo cow as dummy and were under a weekly collection schedule for more than a year period before the beginning of the experiment. Each seminal collection attempt was preceded by a fake mount, aiming higher sperm concentration. For each OPU session $(n=3)$ a different seminal donor was used. 
Immediate evaluations: motility was evaluated subjectively under a light microscope (200x) and samples for concentration and sperm morphology were taken. Sperm samples for concentration were fixed in buffered formol-saline solution (Hancock, 1957) in a 1:200 dilution and count was performed using a hemocytometer chamber (Neubauer) under light microscope (400x) (CBRA, 2013). Sperm morphology was evaluated (200 cells) under phase contrast microscope (1000x). Minimal quality requirements to use ejaculates were total motility $\geq 70 \%$; sperm morphology $\geq 80$ normal; sperm concentration $\geq 0.9 \times 10^{9}$ spermatozoa/mL (CBRA, 2013).

Post seminal handling evaluations: sperm motility was evaluated by computer assisted analyzer (Sperm Class Analyzer - SCA ${ }^{\circledR}$ v.4.0) immediately post- final dilution ( 0 h), after 4 and $24 \mathrm{~h}$. of incubation at $5^{\circ} \mathrm{C}$ and post-thaw (frozen aliquots) after 5 minutes of incubation at $37^{\circ} \mathrm{C}$. Setups of the SCA were: particle area 20 a 70 microns $^{2}, \mathrm{VCL}-10<$ Slow $<25$; $>25$ Medium < 50; Progressivity - > 70\% straightness, Circular $-<50 \%$ LIN, VAP - average of 5 readings and connectivity - 12. Previous to CASA evaluation an alliquot of each sample was incubated at $37^{\circ} \mathrm{C}$ for $5 \mathrm{~min}$ and thereafter a $5 \mu \mathrm{L}$ volume was placed in between a prewarmed $\left(37^{\circ} \mathrm{C}\right)$ slide and coverslide. Final results expressed the average of 5 fields with a minimum of 200 cells per field. Total motility (TM \%), progressive motility (PM \%), curvilinear velocity ( $\mathrm{VCL} \mu \mathrm{m} / \mathrm{sec}$.), average path velocity (VAP $\mu \mathrm{m} / \mathrm{sec}$.), straight line velocity (VSL $\mu \mathrm{m} / \mathrm{sec}$.), linearity (LIN \%), straightness (STR \%), wobble (WOB \%), lateral head displacement (ALH $\mu \mathrm{m})$ and beat cross frequency (BCF hz) were evaluated. All those parameters were found best correlated with fertility by Farrell et al. (1998). Functional integrity of the plasma membrane was evaluated by the hypoosmotic swelling test (HOST). Fifty microliters of each sample were added to $500 \mu \mathrm{L}$ of a hypoosmotic fructose-sodium citrate solution $(121 \mathrm{mOsm} / \mathrm{L}-2.702 \mathrm{~g}$ of fructose $+1,324 \mathrm{~g}$ of sodium citrate + distillated water q.s. $100 \mathrm{~mL}$ ) and incubated for $30 \mathrm{~min}$. at $37^{\circ} \mathrm{C}$. Thereafter samples were fixed adding $200 \mu \mathrm{L}$ of buffered formol saline. Two hundred cells were examined using a phase contrast microscope (1000x) (Loaiza-Echeverri et al., 2015).

\section{Semen handling}

Post collection, seminal samples were maintained at $37^{\circ} \mathrm{C}$ until final dilution. Each ejaculate was divided in two aliquots, both diluted to obtain $50 \times 10^{6} \mathrm{sperm} / \mathrm{mL}$ using TRIS extender with no glycerol for cooling and with $7 \%$ glycerol for freezing. Diluted seminal samples were packed in $0.5 \mathrm{~mL}$ straws (IMV ${ }^{\circledR}$ Techgias, L'Aigle Cedex, França), and cooling was initiated submerging straws protected in a plastic bag into a recipient with $1.4 \mathrm{~L}$ of water at $27^{\circ} \mathrm{C}$. A cooling rate of $0.25^{\circ} \mathrm{C} / \mathrm{min}$. down to $5^{\circ} \mathrm{C}$ was obtained submerging the water recipient $\left(27^{\circ} \mathrm{C}\right)$ in a basin with $10 \mathrm{~L} \mathrm{o}$ water at $5^{\circ} \mathrm{C}$. Samples aimed at cooling were maintained at $5^{\circ} \mathrm{C}$ until the fertilization process ( 24hs) while samples aimed at freezing were maintained at $5^{\circ} \mathrm{C}$ for 4 hours before freezing. Straws were then frozen in a Styrofoam box $(39 \times 19 \times 30 \mathrm{~cm}), 5 \mathrm{~cm}$ above the nitrogen $\left(\mathrm{N}_{2}\right)$ level for 20 minutes, thereafter they were plunged into the $\mathrm{N}_{2}$. Minimal requirements to use the semen was $\geq 50 \%$ motility for cooled semen and $\geq 30 \%$ of motility for frozen semen.

\section{Seminal extender production}

Extender contained TRIS ( $2.42 \mathrm{~g})$, citric acid (1.36 g), fructose (1.0 g), low density lipoproteins (LDL -10 mL), acetylcysteine $10 \mathrm{mM}, 0.5 \%$ of soya lecithin (Solec FP- $40^{\circledR}$ - Solae), Equex $0.4 \%$, amikacin $\left(83.4 \mu \mathrm{g} / \mathrm{mL}\right.$ ), and autoclaved Milli-Q ${ }^{\circledR} \mathrm{H}_{2} \mathrm{O}$ (s.q.f. $100 \mathrm{~mL}$ ). All reagents were SigmaAldrich $^{\circledR}$. Half of each batch was used for cooling and the other half was used for freezing semen adding $7 \%$ of glycerol. Extender was preserved cooled at $5^{\circ} \mathrm{C}$ for immediate use (within $24 \mathrm{~h}$.) and was kept frozen $\left(-20^{\circ} \mathrm{C}\right)$ until just prior subsequent uses. Low density lipoproteins were extracted from fresh chicken eggs following the technique proposed by Moussa et al. (2002) with few modifications suggested by Neves (2008). 


\section{In vitro production of embryos}

OPU and initial handling: a total of three OPU sessions were done by an experienced technician. At each session 16 to 25 female buffalo were used and average interval between sessions was 30 days. For OPU donors were immobilized in a cattle crush and $2 \mathrm{~mL}$ of lidocaine $2 \%$ (Lidovet ${ }^{\circledR}$, Bravet) was used for low epidural anesthesia. A Mindray ${ }^{\circledR}$ DP-2200 ultrasound linked to a micro convex multifrequency probe adjusted to $7.5 \mathrm{MHz}$ frequency was used for OPU. Aspiration guide (WTA - Watanabe Tecnologia Aplicada ${ }^{\circledR}$ ) was coupled to the probe and a $18 \mathrm{G}$ needle (WTA - Watanabe Tecnologia Aplicada ${ }^{\circledR}$ ) linked to a Teflon duct of $1.8 \mathrm{~mm}$ diameter and $1.2 \mathrm{~m}$ long were used to collect the follicular fluid.

Before each sessions all ducts were washed with prewarmed $\left(37^{\circ} \mathrm{C}\right)$ Dulbeco modified phosphate buffered saline (DMPBS - Biodux ${ }^{\circledR}$ ), added with $1 \mathrm{~mL}$ of suine sodium heparin (5.000 UI/mL; Hepamax-s ${ }^{\circledR}$, BLAU Pharmaceutics S.A.) per liter of DMPBS. Eigthy five $\mathrm{mmHg}$ vacuum pressure (12 to $15 \mathrm{~mL}$ of water/minutes) was used for follicular aspiration. All follicles of $\geq 2,0 \mathrm{~mm}$ diameter were aspirated, and follicular fluids were gathered in conic prewarmed flasks. Under a controlled ambiance, immediately after aspiration of a group of 4 donors, follicular fluid was filtered (embryo filter - WTA - Watanabe Tecnologia Aplicada ${ }^{\circledR}$ ) and oocytes were then washed in $70 \mu \mathrm{L}$ drops of TCM 199 Hepes $+10 \%$ bovine fetal serum (BFS) $+22 \mu \mathrm{g} / \mathrm{mL}$ pyruvate $+83,4 \mu \mathrm{g} / \mathrm{mL}$ amikacin and thereafter conditioned in $2 \mathrm{~mL}$ cryotubes containing the same media. Cryotubes were immediately placed and subsequently transported to the laboratory in an incubator (WTA - Watanabe Tecnologia Aplicada ${ }^{\circledR}$ ) at $38^{\circ} \mathrm{C}$. Maximal time elapsed between first ovum pickup and arrival at the laboratory was 5 hs.

Oocyte laboratory handling: oocytes were matured in TCM-199 supplemented with BSA, antioxidants, hormones, amikacin and BFS and incubated at $38.8^{\circ} \mathrm{C}$ with $5 \% \mathrm{CO}_{2}$ atmosphere for 22 hours. Thereafter oocytes were washed in Tyrode's-albumin-lactate-pyruvate (TALP) media and divided in two groups equally balanced according to their quality parameters as described by Di Francesco et al. (2011) for buffalos. For the fertilization process, either with cooled or frozen semen, oocytes were accommodated in a $70 \mu \mathrm{L}$ TALP + BSA drop supplemented with heparin, PHE solution and amikacin under mineral oil and incubated at $38.8^{\circ} \mathrm{C}$ with $5 \% \mathrm{CO}_{2}$ for 21 hours.

Sperm cells were selected by two consecutive centrifugations. Firstly, semen was gently dropped over a percoll solution previously warmed to $38.8^{\circ} \mathrm{C}$ for 5 minutes and centrifuged for two minutes at 5500 RPM. The supernatant was withdrawn and one $\mathrm{mL}$ of TALP was added for the second centrifugation as previously described. Eight $\mu \mathrm{L}$ of the precipitate was added in each drop containing oocytes. After the fertilization incubation period presumable zygotes of both groups were denuded and incubated under mineral oil in $60 \mu \mathrm{L}$ of synthetic oviductal fluid (SOF) supplemented with BSA, amino acids, antioxidants, amikacin and BFS in a $5 \% \mathrm{CO}_{2}, 5 \% \mathrm{O}_{2}$, $90 \% \mathrm{~N}$ and saturated humidity atmosphere at $38,8^{\circ} \mathrm{C}$. Feedings were performed on days three and five withdrawing $45 \mu \mathrm{L}$ of the culture media and adding the same amount of SOF. Cleavage and blastocyst rates were evaluated, respectively, on days three and six (Figure 1).

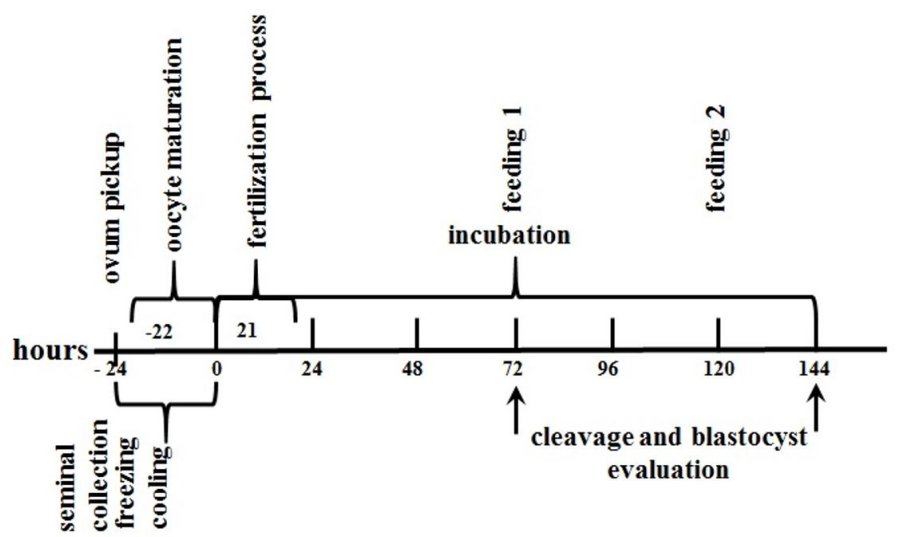

Figure 1. Timeline of PIVE stages in buffalo. 


\section{Statistical analysis}

Seminal data were analyzed by the Statacorp software (Statacorp, 2012) and the T test was used for independent samples. For IVEP data, a descriptive analysis was included, and the "Z" test was used.

\section{Results}

Characteristics of buffalo's ejaculates evaluated immediately post collections are presented in table 1 and kinetics parameters of diluted (immediately post final dilution), cooled and postthaw sperm cells used for in vitro production of embryos and evaluated by the Sperm Class Analyzer - (SCA ${ }^{\circledR}$ v.4.0) are shown in Table 2.

Table 1. Buffalo's ejaculates characteristics evaluated immediately post-collection

\begin{tabular}{|c|c|c|c|c|c|c|c|}
\hline Buffalo & $\begin{array}{c}\text { Volume } \\
\text { (mL) }\end{array}$ & $\begin{array}{c}\text { Mass } \\
\text { motility } \\
(0-5)\end{array}$ & $\begin{array}{c}\text { Motility } \\
(\%)\end{array}$ & $\begin{array}{c}\text { Vigor (0- } \\
5)\end{array}$ & $\begin{array}{c}\text { Concentration } \\
\left(\times 10^{6} / \mathrm{mL}\right)\end{array}$ & MD (\%) & $\mathbf{N}(\%)$ \\
\hline 1 & 1.5 & 3 & 80 & 4 & 1350 & 9 & 87 \\
\hline 2 & 1.8 & 3 & 90 & 4 & 1580 & 10 & 83 \\
\hline 3 & 2.1 & 3 & 80 & 3 & 930 & 8 & 88,5 \\
\hline Mean \pm SD & $1.8 \pm 0,3$ & $3.0 \pm 0,0$ & $83.3 \pm 5,8$ & $3.7 \pm 0.6$ & $1286.7 \pm 329.6$ & $9.0 \pm 1.0$ & $86.1 \pm 2.8$ \\
\hline
\end{tabular}

$\mathrm{MD}$ = major defects; $\mathrm{N}=$ morphologically normal sperm cells and $\mathrm{SD}=$ Standard deviation.

Table 2 - Mean and standard deviation of kinetics parameters of buffalo's spermatozoa evaluted by the CASA at time "0" (immediately post-dilution before cooling), 4 and 24 hs after cooling $\left(5^{\circ} \mathrm{C}\right.$ ) and immediately post thaw.

\begin{tabular}{ccccc} 
Kinetics & \multicolumn{4}{c}{ Time of observation } \\
parameters & Oh & 4h & 24h & PT \\
\hline TM $(\%)$ & $97.0 \pm 1.0^{\mathrm{a}}$ & $95.0 \pm 1.0^{\mathrm{a}}$ & $90.3 \pm 2.1^{\mathrm{b}}$ & $60.3 \pm 3.2^{\mathrm{c}}$ \\
\hline $\mathrm{PM}(\%)$ & $85.3 \pm 915^{\mathrm{a}}$ & $77.3 \pm 6.1^{\mathrm{b}}$ & $64.3 \pm 6.0^{\mathrm{c}}$ & $41.3 \pm 4.0^{\mathrm{d}}$ \\
\hline VCL $(\mu \mathrm{m} / \mathrm{s})$ & $104.8 \pm 15.9^{\mathrm{a}}$ & $94.3 \pm 0.5^{\mathrm{b}}$ & $88.4 \pm 7.6^{\mathrm{b}}$ & $53.9 \pm 0.7^{\mathrm{c}}$ \\
\hline VAP $(\mu \mathrm{m} / \mathrm{s})$ & $72.8 \pm 7.3^{\mathrm{a}}$ & $66.0 \pm 5.4^{\mathrm{b}}$ & $63.8 \pm 5.1^{\mathrm{b}}$ & $42.1 \pm 0.8^{\mathrm{c}}$ \\
\hline VSL $(\mu \mathrm{m} / \mathrm{s})$ & $49.2 \pm 5.6^{\mathrm{a}}$ & $46.2 \pm 10.3^{\mathrm{a}}$ & $44.4 \pm 9.7^{\mathrm{b}}$ & $32.3 \pm 1.2^{\mathrm{c}}$ \\
\hline LIN $(\%)$ & $47.9 \pm 10.1^{\mathrm{b}}$ & $49.5 \pm 11.6^{\mathrm{b}}$ & $49.3 \pm 7.2^{\mathrm{b}}$ & $59.3 \pm 1.1^{\mathrm{a}}$ \\
\hline STR $(\%)$ & $67.9 \pm 8.6^{\mathrm{b}}$ & $69.0 \pm 10.0^{\mathrm{b}}$ & $69.0 \pm 11.2^{\mathrm{b}}$ & $79.4 \pm 0.6^{\mathrm{a}}$ \\
\hline WOB $(\%)$ & $70.0 \pm 6.7^{\mathrm{b}}$ & $70.1 \pm 6.1^{\mathrm{b}}$ & $71.8 \pm 5.1^{\mathrm{b}}$ & $77.3 \pm 1.5^{\mathrm{a}}$ \\
\hline ALH $(\mu \mathrm{m})$ & $3.7 \pm 0.6^{\mathrm{b}}$ & $3.3 \pm 0.2^{\mathrm{b}}$ & $3.2 \pm 0.2^{\mathrm{b}}$ & $2.2 \pm 0.1^{\mathrm{a}}$ \\
\hline BCF $(\mathrm{Hz})$ & $9.3 \pm 1.0^{\mathrm{b}}$ & $10.1 \pm 0.6^{\mathrm{a}}$ & $10.4 \pm 1.8^{\mathrm{a}}$ & $10.0 \pm 0.2^{\mathrm{a}}$ \\
\hline
\end{tabular}

Average of 3 donors, 1 ejaculate per donor; samples were pre warmed to $37^{\circ} \mathrm{C}$; different letters in the row indicates $\mathrm{p}<0,05$; PT: post-thaw; TM: total motility; PM: progressive motility; VCL: curvilinear velocity; VAP: average path velocity; VSL: straight line velocity; LIN: Linearity; STR: straightness; WOB: wobble; ALH: lateral head displacement; BCF: beat cross frequency.

Sperm plasmatic membrane integrity evaluated by the HOST (\% reactive cells) was $94.1 \pm 2.9^{\mathrm{a}}, 92.2 \pm 3.2^{\mathrm{a}}, 89.9 \pm 1.5^{\mathrm{a}}$ and $58.6 \pm 2.5^{\mathrm{b}} \%$ (mean \pm standard deviation) respectively for immediately post-dilution $\left(37^{\circ} \mathrm{C}\right)$, after 4 and 24 hours at $5^{\circ} \mathrm{C}$ and immediately post thaw . Values did not decrease after 4 or 24 hours of cooling but was less for frozen-thawed sperm cells $(P<0.05)$.

The OPU session ( $n=3$ ) yield and the efficiency of IVEP in buffalos per OPU session and type of semen (cooled $x$ frozen) are presented in Table 3. It can be observed that despite OPU sessions were performed out of the local physiological breeding period, in all three attempts follicular growth activity on the ovaries allowed a rather good success of oocytes recovery. Additionally, IVEP efficiency was higher when cooled semen was used in comparison to frozen semen. 
Table 3. Ovum pick up (OPU) in bufalos (Bubalus bubalis) - results per session ( $\mathrm{n}=3$ - thirty days intersessions interval - from September to November) and in vitro embryo production (IVEP) using cooled or frozen sperm cells.

\begin{tabular}{|c|c|c|c|c|c|c|c|c|}
\hline \multirow{2}{*}{\multicolumn{3}{|c|}{ OPU variables }} & \multicolumn{6}{|c|}{ OPU Session } \\
\hline & & & \multicolumn{2}{|c|}{$1^{\mathrm{a}}$} & \multicolumn{2}{|c|}{$2^{a}$} & \multicolumn{2}{|c|}{$3^{a}$} \\
\hline \multicolumn{3}{|c|}{$\mathrm{N}^{\circ}$ of aspirated donors } & \multicolumn{2}{|c|}{20} & \multicolumn{2}{|c|}{25} & \multicolumn{2}{|c|}{16} \\
\hline \multicolumn{3}{|c|}{$\mathrm{N}^{\circ}$ of aspirated follicles } & \multicolumn{2}{|c|}{161} & \multicolumn{2}{|c|}{140} & \multicolumn{2}{|c|}{139} \\
\hline \multicolumn{3}{|c|}{ Average number of follicles/donor } & \multicolumn{2}{|c|}{8.1} & \multicolumn{2}{|c|}{$5 . .6$} & \multicolumn{2}{|c|}{8.7} \\
\hline \multicolumn{3}{|c|}{ Total number of retrieved oocytes } & \multicolumn{2}{|c|}{130} & \multicolumn{2}{|c|}{105} & \multicolumn{2}{|c|}{94} \\
\hline \multicolumn{3}{|c|}{ Oocyte recovery rate $(\%)$} & \multicolumn{2}{|c|}{81} & \multicolumn{2}{|c|}{75} & \multicolumn{2}{|c|}{68} \\
\hline \multicolumn{3}{|c|}{$\mathrm{N}^{\circ}$ of retrieved viable oocytes (grading I, II e III) } & \multicolumn{2}{|c|}{102} & \multicolumn{2}{|c|}{80} & \multicolumn{2}{|c|}{57} \\
\hline \multicolumn{3}{|c|}{ No viable oocyte rate (\%) } & \multicolumn{2}{|c|}{28} & \multicolumn{2}{|c|}{25} & \multicolumn{2}{|c|}{27} \\
\hline \multicolumn{3}{|c|}{ Viable oocyte rate (\%) } & & & & & & .4 \\
\hline Average retrieved oocyte nur & er/do & & & & & & & \\
\hline & & & OPU & sion & & & & \\
\hline OPU variables & & & & & & & & \\
\hline tr vantadics & Sem & type & Sem & type & Sem & type & & \\
\hline & CS & FS & CS & FS & CS & FS & CS & FS \\
\hline $\mathrm{N}^{\circ}$ of matured oocytes & 51 & 51 & 40 & 40 & 27 & 30 & 118 & 121 \\
\hline $\mathrm{N}^{\circ}$ of cultured oocytes & 41 & 30 & 34 & 32 & 27 & 30 & 102 & 92 \\
\hline $\mathrm{N}^{\circ}$ of cleaved oocytes & 16 & 13 & 11 & 6 & 8 & 4 & $35^{a}$ & $23^{b}$ \\
\hline $\mathrm{N}^{\circ}$ of produced embryos & 16 & 12 & 7 & 5 & 7 & 0 & $30^{a}$ & $17^{b}$ \\
\hline$\%$ of cleaved/cultured oocytes & 31 & 24 & 18 & 13 & 18 & 0 & $25.4^{a}$ & $14.0^{\mathrm{b}}$ \\
\hline$\%$ of embryos/matured oocytes & 39 & 40 & 21 & 16 & 26 & 0 & $29.4^{a}$ & $18.5^{b}$ \\
\hline$\%$ of embryos/cleaved oocytes & 100 & 92 & 64 & 83 & 88 & 0 & 85.7 & 73.9 \\
\hline
\end{tabular}

Different letters in a row indicates $\mathrm{P}<0.05$; CS: cooled semen; FS: frozen semen; comparison was made using the $Z$ test. Total $=$ Session $1+2+3$

\section{Discussion}

The use of cooled semen for in vitro production of buffalo embryos showed to be an effective alternative compared to the use of frozen semen.

As far as seminal characteristics of the three seminal donors is concerned values were within the expected range for the species (CBRA, 2013; Henry et al., 2017). Besides that, seminal parameters per se expressed good fertilization potential (Severo, 2009), it is worth to stress that donors were under a weekly long-lasting seminal collection schedule which lessen aging sperm cells within the epididymis tail favoring good sperm quality.

The aim of choosing 24 hours of cooling was based on the speculation that this length of time would better represent what is feasible to transport semen from a farm (origin of a seminal donor) to a IVEP laboratory, this, considering the extension of the country were the experiment was achieved. As expected, a decrease in TM, PM, VCL, VAP and in VSL was observed in post thaw sperm cells and in cells maintained at $5^{\circ} \mathrm{C}$ for $24 \mathrm{hs}$. The drop was more substantial for frozen/thawed sperm cells (fluctuating between 35 and $50 \%$ - $(P<0.05)$ while the major drop for cooled sperm cells was about $25 \%$ for PM and velocity parameters decreased by $15 \%$ or even less among seminal donors. In both type of semen, VCL, VSL, LIN and ALH values did not characterize any sperm hyperactivation (Gillan et al., 2008) which could be detrimental for the whole process.

Sperm characteristics after thaw were within the range reported for buffalos by (ElSisy et al., 2007; Mahmoud et al., 2013, 2015b) and after $24 \mathrm{hs}$ of incubation at $5^{\circ} \mathrm{C}$ similar to the studies of Akhter et al. (2011); Singh et al. (2012); Almeida et al. (2016); Becerra (2017). Additionally, sperm kinetics parameters related to fertility described by Matos et al. (2008) (VCL and ALH), Mortimer (2000) and Verstegen et al. (2002) (VCL, VAP, VSL, BCF and LIN) were within an acceptable range before the fertilization procedure. Thus, the fertilization capacity of sperm 
cells preserved either by cooling or freezing was promising, particularly considering that in vitro fertilization was the goal.

OPU sessions in the present study occurred from September to November. Average follicle punctured per donor varied from 5.6 to 8.7 which is close to numbers found by Sá et al. (2009), Gasparrini et al. (2014) and Pereira (2015). A higher number of follicles per donor (from 12.6 to 15.6) was reported by Ferraz et al. (2015), Ohashi et al. (2017) and Marin et al. (2019) selecting donors with higher number of follicles, reported an average 13.6 follicle per female. Average number of recovered oocytes per donor and session varied from 4.2 to 6.5 above the number $(n=3.7)$ found by Pereira (2015), while Ohashi et al. (2017) and Marin et al. (2019), using a population of donors with higher number of follicles found an average of 7.8 and 10.2 oocytes per donor, respectively. Oocyte recovery rate obtained in the present study (68 to $81 \%$ ) was above that reported by Sá et al. (2009) (57.7\%) and Pereira (2015) (35\%).

Considering the efficiency of the OPU obtained by the end of each session, including oocyte yield and quality oocytes grading, in all three attempts it was decided to proceed with the IVEP. Thus, the oocytes collected were considered adequate to analyze comparatively the efficiency of using cooled versus frozen sperm cells.

Values obtained to percentage of cleaved/cultured oocytes, percentage of embryos/matured oocytes, percentage of embryos/cultivated oocytes and of embryos/cleaved oocytes are within the expected values for the species. Cleaved rate of $41.7 \% ; 67.5 \% ; 38.7 \%$ (October to February), 63.4\% (March to June) and 33.4\% were reported by Gasparrini et al. (2014), Pereira (2015) and Ferraz et al. (2015), respectively. This indicates that our laboratory procedures were consistent with the ongoing procedures.

\section{Cooled sperm and fertilization capacity}

The feasibility of the use of cooled semen to fertilize buffalo oocytes in vitro was evident based on percentage of cleaved/cultured oocytes (34.3\%) and of embryos/cleaved oocytes (85.7\%). These results were obtained even using the three types of oocytes quality grading (I to III) which maintained a similar proportion for the three OPU session. Additionally, no special laboratory process was used to prepare cooled sperm cells for the fertilization capacity test. Efficiency was similar for the three seminal donors despite that seminal different fertilizing capacity in vitro may be expected between buffalo seminal donors (Totey et al., 1992; Zicarelli et al., 2009). In natural breeding or conventional artificial insemination difference in fertility between bulls has been reported (Saacke et al., 1998). Thus, the process of cooling instead of freezing did not alter/suppress sperm cells ability to capacitate and go through acrosome reaction and fertilize the oocytes.

\section{Fertilization capacity of cooled $\mathbf{x}$ frozen/thawed sperm cells}

The in vitro fertilization capacity of cooled semen was superior to that of frozen/thawed semen. This was observed by the superior index of embryos/matured $(25.4 \times 14.0 \%)$ and of embryos/cultivated oocytes $(29.4 \times 18.5 \%)$ in favor of the cooled sperm cells $(P<0.05)$. Once oocytes were fertilized the percentage of embryos per cleaved oocyte was similar between type of sperm cells. An effect of ejaculate can be excluded once the same ejaculate of each seminal donor was used simultaneously to either cool or freeze. Additionally, the same trend was observed for the three seminal donors, i.e. cooled semen was more efficient than frozen semen, this altogether minimize the possibility of an effect of seminal donor. Number of motile sperm cells available for the fertilization as major effect on the results should be minimized or even withdraw considering that through the percoll method a similar number of sperm cells were selected to be incubated with oocytes.

As sperm cells preserved by the two methods were previously selected through the percoll method for the process of fertilization it could be expected that differences found in kinetics parameter between the two types of semen would be minimized or even expunged. It is known that sperm cells submitted to the freezing/thawing processes are more likely to suffer 
cryoinjuries during this process and has a shorter in vitro lifetime that when only cooling is used (Watson, 1995; Bucher et al., 2009; Mahmoud et al., 2015a), particularly for a relatively short period as 24 hours. The motility of cooled semen $\left(5^{\circ} \mathrm{C}\right)$ in several studies could be maintained above 30\% for up to 3 days Singh et al. (2012), Almeida et al. (2016), Becerra (2017) and Almeida (2018), indicating that 24 hs, of incubation was not a crucial length of time as to the maintenance of sperm activity.

In the present study the incubation of oocytes with sperm cells for the occurrence of fertilization lasted for 21 hours. Even though no specific control along the process of incubation was done, it is reckless to attribute the lower efficiency of the frozen semen exclusively to the life span of the cells; differences in sperm kinetics could account for this, however, as cited above, selection of sperm cells by the percoll method was done beforehand and have the theoretical potential to minimize this effect. Therefore, cryoinjuries caused by the freezing/thawing processes other than those already mentioned cannot be excluded as causing factors, alone or in association.

\section{Conclusion}

It is concluded that the semen chilled for 24 hours at $5^{\circ} \mathrm{C}$ proved to be effective in the fertilization of buffalo oocytes by the PIVE technique, presenting results superior to the use of frozen semen.

\section{Acknowledgements}

To the Instituto Nacional de Ciência e Tecnologia (INCT - Pecuária/FAPEMIG/CNPq) and Coordenação de Aperfeiçoamento de Pessoal de Nível Superior (CAPES), for the financial support and scholarship. To the BH Embrions Laboratory, for assigning its laboratory and technicians to carry out the aspiration and in vitro fertilization process.

\section{References}

ABS Brasil [homepage on the Internet]. Delta: ABS Brasil; 2016 [cited 2020 Mar 31]. Available from: http://invitrobrasil.com.br/fiv-bubalinos.php

Akhter S, Ansari MS, Rakha BA, Ullah N, Andrabi SMH, Khalid M. In vitro evaluation of liquid-stored buffalo semen at $5^{\circ} \mathrm{C}$ diluted in soya-lecithin based extender (Bioxcell ${ }^{\circledR}$ ), Tris-citric egg yolk, skim milk and egg yolk-citrate extenders. Reprod Domest Anim. 2011;46(1):45-9. http://dx.doi.org/10.1111/j.1439-0531.2009.01561.x. PMid:20070582.

Almeida J, Becerra VAB, Neves BP, Auler PA, Andrade GO, Brito MF, Henry M. Refrigeração de sêmen bubalino (Bubalus bubalis) frente a diferentes extensores e avaliação da motilidade espermática no CASA. Proceedings of the 30th Annual of the Brazilian Embryo Technology Society (SBTE), Foz do Iguaçú, PR, Brazil. August 25th to 27th, 2016, and 32th Meeting of the European Embryo Transfer Association (AETE), Barcelona, Spain, Septembre 9th and 10th, 2016. Abstracts. Anim Reprod. 2016;13(3):557.

Almeida J. Sêmen refrigerado e seu potencial de uso na inseminação artificial de búfalas (Bubalus bubalis). [tese]. Belo Horizonte: Universidade Federal de Minas Gerais; 2018.

Baruselli PS, Ferreira RM, Vieira LM, Souza AH, Bó GA, Rodrigues CA. Use of embryo transfer to alleviate infertility caused by heat stress. Theriogenology. 2020;155:1-11. http://dx.doi.org/10.1016/j.theriogenology.2020.04.028. PMid:32562738.

Baruselli PS, Mucciolo RG, Visintin JA, Viana WG, Arruda RP, Madureira EH, Oliveira CA, Molero-Filho JR. Ovarian follicular dynamics during the estrous cycle in buffalo (Bubalus bubalis). Theriogenology. 1997;47(8):1531-47. http://dx.doi.org/10.1016/S0093-691X(97)00159-3. PMid:16728096.

Becerra VAB. Efeito da adição de Aniba canelilla, blueberry e polifenol de chá verde sobre a viabilidade in vitro de espermatozoides de búfalo (Bubalus bubalis) resfriados a $5^{\circ} \mathrm{C}$ [dissertação]. Belo Horizonte: Universidade Federal de Minas Gerais; 2017. 
Bernardes J. Nascem bezerras geradas de embriões de animais de dois meses. J. USP. [serial on the Internet]. 2017 [cited 2020 Mar 31];02-05(17). Available from: http://jornal.usp.br/ciencias/cienciasagrarias/nascem-bezerras-geradas-de-embrioes-de-animais-de-dois-meses/

Bucher A, Kasimanickam R, Hall JB, Dejarnette JN, Whittier WD, Kähn W, Xu Z. Fixed-time Al pregnancy rate following insemination with frozen-thawed or fresh-extended semen in progesterone supplemented CO-Synch protocol in beef cows. Theriogenology. 2009;71(7):1180-5. http://dx.doi.org/10.1016/j.theriogenology.2008.12.009. PMid:19195696.

Campanile G, Baruselli PS, Neglia G, Vecchio D, Gasparrini B, Gimenes LU, Zicarelli L, D’Occhio MJ. Ovarian function in the buffalo and implications for embryo development and assisted reproduction. Anim Reprod Sci. 2010;121(1-2):1-11. http://dx.doi.org/10.1016/j.anireprosci.2010.03.012. PMid:20430540.

Colégio Brasileiro de Reprodução Animal - CBRA. Manual para exame andrológico e avaliação de sêmen animal. 3. ed. Belo Horizonte: CBRA; 2013. 104 p.

Danell B. Oestrous behaviour, ovarian morphology and cyclical variation in folicular system and endocrine pattern in water buffalo heifers [thesis]. Sweden: Swedish University of Agricultural Sciences; 1987.

Di Francesco S, Boccia L, Campanile G, Di Palo R, Vecchio D, Neglia G, Zicarelli L, Gasparrini B. The effect of season on oocyte quality and developmental competence in Italian Mediterranean buffaloes (Bubalus bubalis). Anim Reprod Sci. 2011;123(1-2):48-53. http://dx.doi.org/10.1016/j.anireprosci.2010.11.009. PMid:21168984.

El-Sisy GA, EINatat WS, El-Sheshtawy RI. Buffalo semen quality, antioxidants and peroxidation during chilling and cryopreservation. J Vet Res (Pulawy). 2007;11:55-61.

Erickson BH. Development and radio-response of pre-natal bovine ovary. J Reprod Fertil. 1966;10(1):97105. http://dx.doi.org/10.1530/jrf.0.0110097.

Farrell PB, Presicce GA, Brockett CC, Foote RH. Quantification of bull sperm characteristics measured by computer-assisted sperm analysis (CASA) and the relationship to fertility. Theriogenology. 1998;49(4):871-9. http://dx.doi.org/10.1016/S0093-691X(98)00036-3. PMid:10732095.

Ferraz ML, Sá MF Fo, Batista EOS, Watanabe YF, Watanabe MR, Dayan A, Joaquim DC, Accorsi MR, Gimenes LU, Vieira LM, Baruselli PS. Paradoxical effects of bovine somatotropin treatment on the ovarian follicular population and in vitro embryo production of lactating buffalo donors submitted to ovum pickup. Anim Reprod Sci. 2015;154:1-7. http://dx.doi.org/10.1016/j.anireprosci.2014.12.017. PMid:25623138.

Gasparrini B, Neglia G, Di Palo R, Vecchio D, Albero G, Esposito L, Campanile G, Zicarelli L. Influence of oocyte donor on in vitro embryo production in buffalo. Anim Reprod Sci. 2014;144(3-4):95-101. http://dx.doi.org/10.1016/j.anireprosci.2013.11.010. PMid:24374181.

Gasparrini B. Effects of reproductive season on embryo development in the buffalo. Reprod Fertil Dev. 2018;31(1):68-81. http://dx.doi.org/10.1071/RD18315. PMid:32188543.

Gillan L, Kroetsch T, Chis Maxwell WM, Evans G. Assessment of in vitro sperm characteristics in relation to fertility in dairy bulls. Anim Reprod Sci. 2008;103(3-4):201-14. http://dx.doi.org/10.1016/j.anireprosci.2006.12.010. PMid:17208395.

Gimenes LU, Fantinato P No, Arango JSP, Ayres H, Baruselli PS. Follicular dynamics of Bos indicus, Bos taurus and Bubalus bubalis heifers treated with norgestomet ear implant associated or not to injectable progesterone. Anim Reprod. 2009;6:256.

Gimenes LU, Ferraz ML, Araujo A, Fantinato Neto P, Chiarati MR, Mesquita LG, Arango JSP, Raposo M, Souza DC, Calomeni GD, Gardinal R, Rodriguez CLV, Trinca LA, Meirelles FV, Baruselli PS. OPU at different times of a synchronized follicular wave did not affect IVP in Bos indicus, Bos taurus and Bubalus bubalis. Reprod Fertil Dev. 2010;22(1):293-4. http://dx.doi.org/10.1071/RDv22n1Ab273.

Hancock JL. The morphology of boar espermatozoa. J R Microsc Soc. 1957;76(3):84-97. http://dx.doi.org/10.1111/j.1365-2818.1956.tb00443.x. PMid:13476430.

Henry M, Brito MF, Neves BP, Auler PA, Almeida J, Andrade GO, Becerra VB, Bergmann L. Peculiarities of the buffalo species for andrological evaluation-results of four years of study and weekly semen collection schedule. Anim Reprod. 2017;14(Suppl. 1):1225-33. http://dx.doi.org/10.21451/1984-3143AR0005.

Le Van Ty D, Chupin D, Driancourt DA. Ovarian follicular population in buffaloes and cows. Anim Reprod Sci. 1989;19(3-4):171-8. http://dx.doi.org/10.1016/0378-4320(89)90090-0. 
Liang A, Salzano A, D'Esposito M, Comin A, Montillo M, Yang L, Campanile G, Gasparrini B. Anti-Mullerian hormone $(\mathrm{AMH})$ concentration in follicular fluid and mRNA expression of AMH receptor type II and LH receptor in granulosa cells as predictive markers of good buffalo (Bubalus bubalis) donors. Theriogenology. 2016;86(4):963-70. http://dx.doi.org/10.1016/j.theriogenology.2016.03.020. PMid:27087535.

Loaiza-Echeverri AM, Cruz BC, Snoeck PPN, Moura LCO, Neves BP, Neves MM, Heneine LGD, Henry M. Low density lipoproteins added to an extender frozen or lyophilized are evenly efficient in cryoprotecting ovine sperm cells than when 16\% whole egg yolk was added. Semina: Ciênc Agrár. 2015;3(36):1315-46. http://dx.doi.org/10.5433/1679-0359.2015v36n3p1315.

Madan ML, Singla SK, Jain GC. Ovulatory response to different superovulatory treatment amongst buffaloes (Bubalus bubalis). In: Abstract of the 11th International Congress on Animal Reproduction and Al; 1992; Dublin. Dublin: ICAR; 1992.

Mahmoud KGM, El-Sokary AAE, Abou El-Roos MEA, Abdel-Ghaffar AE, Nawito M. Sperm characteristics in cryopreserved buffalo bull semen in relation to field fertility. Iran J Appl Anim Sci. 2013;3(4):777-83.

Mahmoud KGM, El-Sokary AAE, Abdel-Ghaffar AE, Abou El-Roos MEA, Ahmed YF. Analysis of chromatin integrity and DNA damage in cryopreserved buffalo semen. Iran J Vet Res. 2015a;16(2):161-6.

Mahmoud KGM, Scholkamy TH, Darwish SF. Improvement of vitrification of in vitro produced buffalo embryos with special reference to sex ratio following vitrification. Iran J Vet Res. 2015b;16(4):325-30. PMid:27175197.

Marin DFD, Souza EB, Brito VC, Nascimento CV, Ramos AS, Rolim ST Fo, Costa NN, Cordeiro MS, Santos SSD, Otavio Mitio Ohashi OM. In vitro embryo production in buffaloes: from the laboratory to the farm. Anim. Reprod. 2019;16(2):260-66. http://dx.doi.org/10.21451/1984-3143-AR2018-0135.

Matos DL, Araújo AA, Roberto IG, Toniolli R. Análise computarizada de espermatozoides: revisão de literatura. Rev Bras Reprod Anim. 2008;32(4):225-32.

Mortimer ST. Casa-practical aspects. J Androl. 2000;21(4):515-24. http://dx.doi.org/10.1002/j.19394640.2000.tb02116.x. PMid:10901437.

Moussa M, Marinet V, Trimeche A, Tainturier D, Anton M. Low density lipoproteins: extracted from hen egg yolk by an easy method: cryoprotective effect on frozen-thawed bull semen. Theriogenology. 2002;57(6):1695-706. http://dx.doi.org/10.1016/S0093-691X(02)00682-9. PMid:12035979.

Neves MM. Extração das lipoproteínas de baixa densidade da gema do ovo de Gallus domesticus e sua aplicação na criopreservação do sêmen canino [tese]. Belo Horizonte: Universidade Federal de Minas Gerais; 2008.

Ocampo MB, De Assis AT, Ocampo LC, Kanagawa H. Histological observation of follicular atresia in Swamp buffalo. Buffalo Bull. 1994;13(3)

Ohashi OM, Cordeiro MS, Miranda MS. Biotecnologia da reprodução aplicada a bubalinos. Rev. Cienc. Agrar. 2006;45:58-63.

Ohashi OM, Costa Almeida NN, Cordeiro MS, Rolim ST Fo, Ribeiro HFL, Santos AX, Ayala HMD, Brito VC, Ramos AS, Silva TVG, Santos SSD, Miranda MS. Produção in vitro de embrião (PIVE) na espécie bubalina. Rev Bras Reprod Anim. 2017;41(1):195-200.

Ohashi OM, Miranda MS, Souza J, Cordeiro MS, Biondi FC. Produção in vitro de embrião bubalino. Rev Bras Reprod Anim. 2003;27:103-9.

Pereira ECM. Produção de oócitos e embriões bubalinos: efeitos da época do ano e da adição de óleo essencial de Lippia origanoides na maturação in vitro [tese]. Botucatu: Faculdade de Medicina Veterinária e Zootecnia, Campus Botucatu, Universidade Estadual Paulista; 2015.

Perera BMAO. Reproductive cycles of buffalo. Anim Reprod Sci. 2011;124(3-4):194-9. http://dx.doi.org/10.1016/j.anireprosci.2010.08.022. PMid:20869822.

Sá MF Fo, Carvalho NAT, Gimenes LU, Torres-Júnior JR, Nasser LFT, Tonhati H, Garcia JM, Gasparrini B, Zicarelli L, Baruselli PS. Effect of recombinant bovine somatotropin (bST) on follicular population and on in vitro buffalo embryo production. Anim Reprod Sci. 2009;113(1-4):51-9. http://dx.doi.org/10.1016/j.anireprosci.2008.06.008.

Saacke RG, DeJarnette JM, Bame JH, Karabinus DS, Whitman S. Can spermatozoa with abnormal heads gain access to the ovum in artificially inseminated super and single-ovulating cattle? Theriogenology. 1998;50(1):117-28. http://dx.doi.org/10.1016/S0093-691X(98)00119-8. PMid:10734480. 
Salzano A, De Canditiis C, Della Ragione F, Prandi A, Zullo G, Neglia G, Campanile G, Gasparrini B. Evaluation of factors involved in the failure of ovum capture in superovulated buffaloes. Theriogenology. 2018;122:102-8. http://dx.doi.org/10.1016/j.theriogenology.2018.09.007. PMid:30245332.

Santos SSD, Ferreira MAP, Sampaio RV, Costa NN, Santos DCN, Santana PPB, Sá ALA, Silva BB, Cordeiro MS, Silva TVG, Miranda MS, Ohashi OM. Evaluation of apoptosis as a mechanism of follicular cell atresia in the ovaries of cattle (Bos indicus) and buffalo (Bubalus bubalis) fetuses. Anim Reprod. 2013;10(1):55-61.

Severo NC. Influência da qualidade do sêmen bovino congelado sobre a fertilidade. A Hora Veterinária [serial on the Internet]. 2009 [cited 2020 Jan 28];28(167):36-9. Available from: http://revivah.com.br/site/wp-content/uploads/2015/04/Bovinos-Qualidade-do-S\%C3\%AAmenCongelado-Fertilidade-2009.pdf

Singh AK, Singh VK, Narwade BM, Mohanty TK, Atreja SK. Comparative quality assessment of buffalo (Bubalus bubalis) semen chilled $\left(5^{\circ} \mathrm{C}\right)$ in egg yolk- and soya milk-based extenders. Reprod Domest Anim. 2012;47(4):596-600. http://dx.doi.org/10.1111/j.1439-0531.2011.01928.x. PMid:22017209.

Soliman WTM, Mahmoud KGhM, El-Khawagah ARM, Kandiel MMM, Abouel-Roos MEA, Abdel-Ghaffar AE, El Azab AEI. Impact of in vitro fertilization by fresh and frozen semen on developmental competence and cryotolerance of buffalo embryos. 2018;19(3):178-81. http://dx.doi.org/10.22099/IJVR.2018.4935. PMid: 30349563.

Statacorp. Stata: Release 12. Statistical Software. College Station, TX: Statacorp LP; 2012.

Surresh KP, Nandi S, Mondal S. Factors affecting laboratory production of buffalo embryos: a metaanalysis. Theriogenology. 2009;72(7):978-85. http://dx.doi.org/10.1016/j.theriogenology.2009.06.017. PMid:19695691.

Totey SM, Singh G, Taneja M, Pawshe CH, Talwar GP. In vitro maturation, fertilization and development of follicular oocytes from buffalo (Bubalus Bubalis). J Reprod Fertil. 1992;95(2):597-607. http://dx.doi.org/10.1530/jrf.0.0950597. PMid:1518014.

Verstegen J, Iguer-Ouada M, Onclin K. Computer assisted semen analyzers in andrology research and veterinary pratice. Theriogenology. 2002;57(1):149-79. http://dx.doi.org/10.1016/S0093691X(01)00664-1. PMid:11775967.

Vitoria A. Anatomy of female genital tract in the buffalo. In: Course on biotecnology of reproduction in buffaloes. Vol. 4. Caserta, Italy: Journal of Buffalo Science; 1997; Suppl 1, p. 15-20.

Watson PF. Recent development and concepts in the cryopreservation of spermatozoa and the assessment of their post-thawing function. Reprod. Fertil. Dev. 1995;7(4):871-91. http://dx.doi.org/10.1071/RD9950871. PMid: 8711221.

Zicarelli L, Mariotti E, Di Francesco S, Velotto S, Rubessa M, Neglia G. Effect of bull on in vitro sperm capacitation induced by different agents in buffalo species (Bubalus bubalis). Ital J Anim Sci. 2009;8(suppl 2):177-9. http://dx.doi.org/10.4081/ijas.2009.s2.177.

\section{Author contributions}

JA: Writing - original draft and Investigation; BPN: Methodology; MFB: Project administration; RFF: Methodology ; LGL: Supervision; LSG: Data curation; JPH: Formal Analysis; PAA: Visualization, MH: Supervision and Writing - review \& editing. 